\title{
NOTES
}

\section{CONGRESSIONAL DELEGATION OF ADJUDICATORY POWER TO FEDERAL AGENCIES AND THE RIGHT TO TRIAL BY JURY}

The continued growth of the administrative bureaucracy and its increased impact on the rights and duties of citizens is a well-documented phenomenon of the twentieth century. ${ }^{1}$ At the federal level, bureaucracy flourishes as Congress delegates ever more responsibility to agencies. ${ }^{2}$ Within their statutorily defined fields, federal agencies typically perform the functions of rulemaking, enforcement and adjudication. ${ }^{3}$ This note focuses on the adjudicatory function ${ }^{4}$ and considers whether, when Congress creates a new statutory cause of action, ${ }^{5}$ the seventh amendment ${ }^{6}$ limits Congress's ability to delegate responsibility for adjudicating cases under that statute to a federal administrative tribunal rather than an arti-

1. See J. Freedman, Crisis and legitimacy: The Administrative Process and American Government 3-5 (1978). The Interstate Commerce Commission, created in 1887, is regarded by administrative law academics as the first of the modern administrative agencies. Fallon, Of Legislative Courts, Administrative Agencies, and Article III, 101 HARv. L. REv. 915, 923 n.50 (1988).

2. See J. Freedman, supra note 1, at 5 ("Under Democratic and Republican Presidents alike, Congress has regularly chosen to rely upon administrative regulation-rather than upon civil remedies, criminal penalties, subsidies to the private sector, or the free-market ... - to implennent public policies in new and complex areas of federal concern.").

3. W. GellhorN, C. BYSE, P. Strauss, T. RAKoFf \& R. SchotLaNd, ADMinistrative LAW 1 (8th ed. 1987). "Agency," for the purposes of this note, includes both executive branch agencies and independent regulatory agencies.

4. The note analyzes the impact of the seventh amendment on administrative adjudications. Since the seventh amendment does not apply to the states, see Walker v. Sauvinet, 92 U.S. 90,92 (1876), the focus is limited to the federal administrative bureaucracy.

5. See, eg., S. 558, 100th Cong., 1st Sess., 133 Cong. Rec. S2256 (daily ed. Feb. 19, 1987) (bill introduced to amend Fair Housing Act by providing for new administrative enforceinent inechanism). This bill provides a useful example of the issues raised in seventh amendment challenges and will be referred to frequently. The Senate Judiciary Committee's Subcommittee on the Constitution has held hearings on whether the enforceinent provisions of $S .558$ violate the seventh amendment. See [1987-1988] 1 Cong. Index (CCH) 21,008. The Subcommittee approved S. 558 by a four-to-one vote on June 23, 1987. See 45 CoNG. Q. WeEkLY ReP. 3227 (1987).

6. "In Suits at common law, where the value in controversy shall exceed twenty dollars, the right of trial by jury shall be preserved, and no fact tried by jury, shall be otherwise re-examined in any Court of the Umited States, than according to the rules of the common law." U.S. CoNST. amend. VII. 


\section{cle III court. ${ }^{7}$}

This area of administrative law currently suffers from a confusion that the Supreme Court has yet to clarify, in part because Congress has not yet breached the seventh amendment limit. ${ }^{8}$ This note argues that the seventh amendment does limit Congress's ability to assigu such responsibility to administrative tribunals. It first reviews the seventh amendment caselaw, emphasizing the Supreme Court's seminal decision in Atlas Roofing Co. v. Occupational Safety \& Health Review Commission, ${ }^{9}$ and then compares that jurisprudence with the article III caselaw. ${ }^{10}$ This comparative approach reflects the fact that congressional delegation of adjudicatory responsibility to an administrative agency is subject to both seventh amendment and article III objections. ${ }^{11}$ In fact, the Supreme Court focuses on the same principle- "public rights"-im analyzing the two objections to administrative determination of cases. ${ }^{12}$

The note then considers whether the Supreme Court has established a seventh amendment limit on Congress's ability to delegate adjudicatory authority; concurrently, it surveys the practical policy considerations and constitutional principles apparently at odds im formulatimg the limit. ${ }^{13}$ The note concludes by describing such a seventh amendment limit, based on the Court's opimions and underlying constitutional doctrime. Specifically, when Congress creates statutory causes of action and empowers federal agencies to adjudicate cases under those statutes, Congress can delegate the power to adjudicate private legal rights only if determination of such rights is necessary to implement the underlying regulatory scheine.

7. As article III provides: "The Judicial Power [of the United States] shall extend to all Cases, in Law and Equity, arising under this Constitution, the Laws of the United States, and Treaties made ... under their Authority ...." U.S. CoNsT. art. III, § 2, cl. 1.

8. The Court has granted certiorari in a case that may help define a seventh amendment limit. See Coit Independence Joint Venture v. FirstSouth, F.A., 829 F.2d 563 (5th Cir. 1987), cert granted sub nom. Coit Independence Joint Venture v. FSLIC, 108 S. Ct. 1105 (1988) (No. 87-996). Coit, a creditor of an insolvent savings and loan association in receivership, argues that the statutory grant of exclusive jurisdiction over state law claims to the Federal Savings and Loan Insurance Corporation (the receiver) violates both the seventh amendment right to trial by jury and article III. For a discussion of the argunents in Coit Independence, see Baxter, Life in the Administrative Track: Adminstrative Adjudication of Claims Against Savings Institution Receiverships, 1988 DUKE L.J. 422, 427-28.

9. 430 U.S. 442 (1977); see infra notes $14-71$ and accompanying text.

10. See infra notes 73-109 and accoinpanying text.

11. See, e.g., Coit Independence, 829 F.2d at 564-65; Crowell v. Benson, 285 U.S 22, 37 (1932); Murray's Lessee v. Hoboken Land \& Improvennent Co., 59 U.S. (18 How.) 272, 273 (1856).

12. See infra notes 60-71, 83-124 and accompanying text. Compare Northern Pipeline Constr. Co. v. Marathon Pipe Line Co., 458 U.S. 50 (1982) (plurality opinion) (article III objeetion) with Atlas Roofing, 430 U.S. at 442 (seventh amendment objection).

13. See infra notes $129-48$ and accompanying text. 


\section{Seventh Amendment JuRisprudenCE}

\section{A. The Historical Test.}

The seventh amendment provides that "[i]n Suits at common law, where the value in controversy shall exceed twenty dollars, the right of trial by jury shall be preserved." 14 In construing the amendinent, the Supreine Court has long been guided by the practices of the Enghish courts in 1791, the year of the amendment's adoption. ${ }^{15}$ This "historical test" is rooted in the amendment's language, especially the word "preserved." 16 In United States v. Wonson, the first recorded case discussing the foundations of the seventh ainendment, Justice Story concluded that it is "obvious to every person acquainted with the history of the law" and "[b]eyond all question [that] the common law ... alluded to [in the seventh amendment] is not the common law of any individual state, (for it probably differs in all), but it is the common law of England, the grand reservoir of all our jurisprudence."17 Thus, the "right" preserved in the seventh anendment is the right of trial by jury under the Enghish coinmon law of 1791.

Using a snapshot of Enghish history to interpret the seventh amendment has, however, proven difficult. In 1791, the Enghish law courts were separate and independent from the equity courts, and a jury trial was available only in the law courts. ${ }^{18}$ But "the line between law and equity (and therefore between jury and non-jury trial) was not a fixed and static one."19 This separation was not necessarily determined by the type of case mvolved, or whether a judge or a jury could best address the issues in the case. ${ }^{20}$ The equity courts, rather, existed principally to compensate for the shortcomings of the common law courts and the inadequacy of common law remedies. ${ }^{21}$

14. U.S. CONST. amend. VII.

15. Wolfram, The Constitutional History of the Seventh Amendment, 57 MINN. L. REV. 639, 640 (1973); see also Dimick v. Schiedt, 293 U.S. 474, 476 (1935) ("In order to ascertain the scope and meaning of the Seventh Amendment, resort must be had to the appropriate rules of the common law established at the time of the adoption of that constitutional provision in 1791.").

16. Wolfram, supra note 15 , at 640 . Wolfram notes that, surprisingly, no federal court has justified the use of the historical approach by citing historical materials surrounding the adoption of the seventh amendment, such as The Federalist Papers. Id. at 720.

17. 28 F. Cas. 745, 750 (C.C.D. Mass. 1812) (No. 16,750) (Story, J.).

18. 5 J. MOORE, J. LuCAS \& J. WiCKer, MOORE'S Federal Practice $\{38.08[5 .-1]$ (2d ed. 1987).

19. James, Right to a Jury Trial in Civil Actions, 72 YALE L.J. 655, 658 (1963).

20. Id. at 661 . There were common law suits for which no right to jury trial existed under English common law. See 5 J. MOORE, supra note 18, \{ 38.08[5.-6] (examples include proceedings for disbarment, contempt, habeas corpus and deportation of an alien).

21. Note, The Right to a Nonjury Trial, 74 HARV. L. Rev. 1176, 1179 (1961). 
Consequently, in order to determine the scope of the Enghish coinmon law right to trial by jury as preserved by the seventh amendment, the American courts needed to develop a workable definition of "suits at common law." In this connection, Justice Story wrote in Parsons v. Bedford:

By common law, [the framers] meant what the constitution denominated in the third article "law;" not merely suits, which the common law recognized among its old and settled proceedings, but suits in which legal rights were to be ascertained and determined, in contradistinction to those where equitable rights alone were recognized, and equitable remedies were administered. ... In a just sense, the [seventh] amendment then may well be construed to embrace all suits which are not of equity and admiralty jurisdiction, whatever may be the peculiar form which they may assume to settle legal rights. ${ }^{22}$

The Court thus defined "common law" in the seventh amendment synonymously with "law" in article $\mathrm{III}^{23}$ and broadly construed the amendment to include all suits outside equity and admiralty jurisdiction.

\section{B. A Flexible Interpretation of the Historical Test.}

Although some commentators have argued that the language of the seventh amendment supports a strict historical reading, i.e., that a right to a jury trial should exist only for those actions at common law recognized by the Enghish courts of $1791,{ }^{24}$ the Supreme Court has never adopted this stance. Indeed, the historical interpretation of the amendment has not foreclosed the right to a jury trial under many of the causes of action created in the Umited States since $1791 .^{25}$ As Justice Story in fact recognized in Parsons $v$. Bedford, the seventh amendment guarantees the right to a jury trial whenever "legal rights" are at issue; the right, therefore, is not limited to the "old and settled" proceedings of the common law. ${ }^{26}$ The Court will still look to the Enghish common law of 1791 for guidance but will hold the seventh amendment apphicable if the new action involves the rights and remedies traditionally enforced in actions at law.27

22. 28 U.S. (3 Pet.) 433, 446 (1830) (Story, J.).

23. U.S. CONST. art. III, $\S 2$, cl. 1.

24. See, e.g., Redish, Seventh Amendment Right to Jury Trial: A Study in the Irrationality of Rational Decision Making, 70 Nw. U.L. REv. 486, 531 (1975) (advocating strict historical test); see also James, supra note 19, at 664 (enumerating arguments supporting "a static historical test").

25. Redish, supra note 24 , at 490.

26. Parsons, 28 U.S. (3 Pet.) at 447.

27. See, e.g., Pernell v. Southall Rcalty, 416 U.S. $363,375-76$ (1974) (finding that suit for recovery of property "serves the same essential function" as common law action of ejectunent; upholding right to jury trial). 
In Curtis v. Loether, ${ }^{28}$ the Court first squarely addressed the issue of whether the seventh amendment should apply to post-1791 causes of action created by congressional enactment. Curtis involved a private cause of action under the fair housing provisions of the Civil Rights Act of 1968. ${ }^{29}$ Justice Marshall, speaking for a unanimous Court, held that "[t]he Seventh Amendinent does apply to actions enforcing statutory rights, and requires a jury trial upon demand, if the statute creates legal rights and remedies, enforceable in an action for damages in the ordinary courts of law." 30

The Court recently cited Curtis as precedent in Tull v. United States. ${ }^{31}$ In that case, the government sued a real estate developer for dumping fill on Virginia wetlands. The government sought injunctive rehef and fines exceeding twenty-two million dollars under the Clean Water Act. ${ }^{32}$ The trial court denied the defendant's timely demand for a jury trial, imposed fines and granted the government injunctive rehef. ${ }^{33}$ On appeal the Supreme Court considered the nature of the action and the remedy sought. It articulated a two-part test to determine whether a right to a jury trial exists in a statutory action. The test requires that courts first compare the statutory action at issue to eighteenth-century Enghish actions at law and then examine the remedy prescribed in the statute to determine if it is legal or equitable in nature. ${ }^{34}$ Applying this test in Tull, the Court held that the seventh amendinent guarantees the right to a jury trial on the issue of hability, but not on the issue of damages, when the federal government seeks rehief in federal court under the Clean Water Act. ${ }^{35}$

\section{The Expansion of the Seventh Amendment After the Merger of Law and Equity.}

The merger of law and equity in 1938 under the Federal Rules of

28. 415 U.S. 189 (1974).

29. Id. at 189-90; see Civil Rights Act of 1968, 42 U.S.C. § 3612 (1982).

30. Curtis, 415 U.S. at 194.

31. 107 S. Ct. 1831, 1835 (1987) (citing Curtis, 415 U.S. at 193, 196).

32. 33 U.S.C. $\S \S 1251-1376$ (1982).

33. Tull, $107 \mathrm{~S}$. Ct. at $1833-34$.

34. Id. at 1835. The Court considers the remedy analysis more important "than finding a precisely analogous common law cause of action in determining whether the Seventh Amendment guarantees a jury trial." Id. at 1837.

The Tull Court also admitted that the adjudication of rights in administrative proceedings outside traditional courts of law raised other considerations, such as the practical limitations of a jury trial. Id. at 1835 n.4; see infra note 134 and accompanying text.

35. Tull, 107 U.S. at 1840. 
Civil Procedure ${ }^{36}$ raised new seventh amendment issues. In a series of three cases, the Supreme Court considered the implications of the law and equity merger and dramatically expanded the right to trial by jury. ${ }^{37}$ The historical test remained in seventh amendment jurisprudence, but the Court recognized that the test needed adjustment, since the law/equity (jury/nonjury) distinction had been eliminated. ${ }^{38}$

In the first case, Beacon Theatres, Inc. v. Westover, ${ }^{39}$ the Court considered the seventh amendment implications of a treble damages counterclaim under the antitrust laws and held that, when resolution of legal and equitable claims depends on a determination of the same issues, legal claims must be subimitted to a jury before adjudication of equitable claims. ${ }^{40}$ The Court emplrasized that, unless the plaintiff demonstrates "irreparable harm and imadequacy of legal remedies," it will not grant equitable injunctive relief. ${ }^{41}$ In expanding the "legal" remedies available, the new procedures under the Federal Rules and the Declaratory Judgment Act also "necessarily affected" (i.e., reduced) the province of equity. ${ }^{42}$ The Court thus construed the seventl amendinent as creating a strong preference for jury trials. ${ }^{43}$

The Court reaffirmed and strengthened the Beacon Theatres liolding in Dairy Queen, Inc. v. Wood. ${ }^{44}$ There the Court lield that if a legal claim and various equitable claims involve common factual issues, then the legal claim must be determined first. ${ }^{45}$ The Court empliatically rejected the arguinent that a party has no right to a jury trial if the legal issues are "incidental" to the equitable issues. ${ }^{46}$ The Court reiterated

36. See FED. R. Civ. P. 2 ("There shall be one form of action to be known as 'civil action'.") The original Rules of Civil Procedure were adopted by the Supreme Court and forwarded to Congress pursuant to the Rules Enabling Act. The merger of law and equity became effective on September 16, 1938. See C. WRIGHT, THE LAW OF FEDERAL CourTs $\S 62$, at 403-04 (4th ed. 1983).

37. See Ross v. Bernhard, 396 U.S. 53I, 540 (1970); Dairy Quecn, Inc. v. Wood, 369 U.S. 469, $479-80$ (1962); Beacon Theatres, Inc. v. Westover, 359 U.S. 500, 509 (1959).

38. Cf. James, supra note 19, at 664 (favoring an "elastic construction" of historical test that would accommodate shifts reflecting authentic historical patterns of change).

39. 359 U.S. 500 (1959).

40. Id. at 508 .

41. Id. at 506-07.

42. Id, at 509 .

43. As the Court stated: "[O]nly under the most imperative circumstances, circumstances which in view of the flexible procedures of the Federal Rules we cannot now anticipate, can the right to a jury trial of legal issues be lost through prior determination of equitable claims." Id. at 510-11 (footnote omitted).

44. 369 U.S. 469 (1962).

45. Id. at 479 .

46. Id. at 470 . The Court thus rejected the "equitable clean-up doctrine," which allowed a court of equity to resolve legal claims incidental to the primary equitable claim as a mechanism to avoid the hardships of separate law and equity courts. Commentators, while criticizing the Dainy Queen Court's rationale, have accepted its holding because the need for the clcan-up doctrine disap- 
that the Federal Rules preserve the right to a jury trial and that, by expanding the scope of legal reinedies, procedural changes in the Rules concomitantly expanded the right to a jury trial. ${ }^{47}$

Finally, in Ross v. Bernard, ${ }^{48}$ the Court held that a right to a jury trial exists in a stockholder's derivative suit when the underlying corporate claim is legal, stating that "[t]he historical rule preventing a court of law from entertaining a shareholder's suit on behalf of the corporation is obsolete." 49 The Court did briefly mention one of the assumptions underlying the historical test-the nonstatic character of the line between law and equity. ${ }^{50}$

\section{Seventh Amendment Challenges to Administrative Adjudication.}

The Supreine Court ignores the historical test when confronting seventh amendment objections in cases before administrative tribunals. Instead of focusing on the legal or equitable nature of the action and the remedies sought, ${ }^{51}$ the Court effectively recognizes a third category of civil action-statutory actions before administrative tribunals. ${ }^{52}$ The Court has never held that the seventh amendment guarantees the right to a jury trial in a proceeding before an administrative tribunal. ${ }^{53}$

peared with the merger of law and equity. See Redish, supra note 24, at 497-98. Professor Redish, however, suggests a revitalization of "the classic clean-up doctrine" as a basis for restricting the seventh amendment right to a jury trial. Id. at 530-31.

47. Dairy Queen, 369 U.S. at 472,478 n.19. In its decisiou, the Court pointed to both Rule 18(a), which permits the joinder of legal and equitable claims, and Rule 53(b), which provides that the district court may appoint special masters to assist the jury in those exceptional cases that involve legal issues too complicated for the jury to handle alone.

48. 396 U.S. 531 (1970).

49. Id. at 540. Strict application of the historical test would certainly have labeled a stockholder's suit as equitable. See id. at 534 ("The common law refused ... to permit stockholders to call corporate managers to account in actions at law.").

50. Id. at 533, 539. The Court seems to imply that the Federal Rules interrupted a process that might have culminated in the law courts' recognition of a shareholder's derivative suit. Id. at 53739. This analysis would be consistent with the "elastic construction" of the historical test advocated by Professor James. See James, supra note 19, at 664; supra note 38. In 1791, however, shareholders definitely could not have brought a derivative suit in the law courts. Professor Redish argues that the Ross decision does much more than modernize historical practices to take account of the new procedures: "[it] effectively rejects the dictates of history for no apparent reason other than simple disagreement with the historical practice." Redish, supra note 24, at 501 (footnote omitted).

51. See, e.g., Tull v. United States, $107 \mathrm{~S}$. Ct. 1831, 1835 (1987) (right to jury trial in district court determined by analyzing nature of action and remedy sought).

52. See Note, Article III Implications for the Applicability of the Seventh Amendment to Federal Statutory Actions, 95 YALE L.J. 1459, 1461 n.12 (1986) (noting that Court's interpretation of seventh amendment depends on forum in which action is brought; an identical action may be termed common law suit in article III court, but statutory action in non-article III tribunal).

53. Some coinmentators simply state that the seventh amendment is not applicable to administrative proceedings. See, e.g., F. JAMES \& G. HAZARD, Civil Procedure $\$ 8.1$, at 410 (3d ed. 1985); 5 J. MOORE, supra note 18, I 38.08[5. - 4]. This note argues, however, that the seventh 
The Court first faced a seventh amendment objection to administrative adjudication in a New Deal-era case, National Labor Relations Board v. Jones \& Laughlin Steel Corp. ${ }^{54}$ Under the National Labor Relations Act of 1935, Congress had delegated to the National Labor Relations Board the task of identifying unfair labor practices and ordering an appropriate remedy. ${ }^{55}$ Jones \& Laughlin argued that a Board order to provide back pay as a remedy was equivalent to damages, thus creating a right to a jury trial. Without citimg any authority, the Court held: "The instant case is not a suit at common law or in the nature of such a suit. The procecding is one unknown to the common law. It is a statutory proceeding. ... The contention under the Seventh Amendment is without merit." 56

Jones \& Laughlin remained dornant as seventh amendment precedent until 1974, when the Court "explained" it in Curtis v. Loether: "Jones \& Laughlin inerely stands for the proposition that the Seventh Amendment is generally mapphicable in administrative proceedings, where jury trials would be incoinpatible with the whole concept of administrative adjudication and would substantially interfere with the NLRB's role in the statutory scheme."57 Two months after Curtis, in Pernell v. Southall Realty, the Court again upheld the right to a jury trial in federal proceeding under a statutory cause of action and explained the administrative agency exception in terıns almost identical to those used in Curtis. 58

In Atlas Roofing Co. v. Occupational Safety \& Health Review Commission, the Supreme Court rehed on Jones \& Laughlin, Curtis and Pernell in rejecting a seventh amendment challenge to a statutory scheme that allowed an administrative agency to impose civil penalties on viola-

amendment does restrict the kinds of actions that administrative tribunals may adjudicate without a jury. See infra notes 151-89 and accompanying text.

54. 301 U.S. 1 (1937).

55. Ch. $372, \S 10,49$ Stat. $449,453-55$ (codified as amended at 29 U.S.C. $\S 160$ (1982)); Jones \& Laughlin, 301 U.S. at 24.

56. Jones \& Laughlin, 301 U.S. at 48-49.

57. Curtis v. Loether, 415 U.S. 139, 194 (1974) (footnote omitted) (emphasis added). For support, the Court quoted L. JAFFE, Judicial CONTROL OF AdMINISTRATIVE ACTION 90 (1965). Id. at 194 n.8. Professor Jaffe, however, states that the seventh amendment may exclude the use of an administrative agency as a factfinder or an adjudicatory forum. L. JAFFE, supra ("Where [the seventh amendment] applies it will, of course, exclude the use of an agency either as fact finder or forum.").

58. 416 U.S. 363,383 (1974). Citing the relevant precedent in the landlord/tenant dispute context, the Court stated: "Block v. Hirsh[, 256 U.S. 135 (1921),] merely stands for the principle that the Seventh Amendment is generally inapplicable in administrative proceedings, where jury trials would be incompatible with the whole concept of adınimistrative adjudication."). 
tors of the Occupational Safety and Health Act of 1970.59 A unanimous Court held that "[a]t least in cases in which 'public rights' are being litigated ... the Seventh Amendment does not prohibit Congress from assigning the factfinding function and initial adjudication to an administrative forum with which the jury would be incoinpatible." 60 This "public rights" exception followed not from the historical test, as apphed in the seventh amendment context, but rather from "the proposition that the right to a jury trial turns not solely on the nature of the issue to be resolved but also on the forum in which it is to be resolved." 61 Thus, the Court held that the seventh amendment would not apply to an administrative adjudication even if a jury trial would be required on the same issue in federal court. ${ }^{62}$

In building the "public riglits" exception to the seventh amendment, Justice White, writing for the Court, pursued two lines of reasoning. ${ }^{63}$ He first cited several tax, tax penalty, and customs and immigration penalty cases that recognized, albeit without discussing seventh amendment issues, the authority of administrative agencies to inipose fines. ${ }^{64}$ One of the cited cases, Murray's Lessee v. Hoboken Land \& Improvement Co. ${ }^{65}$ contains what seeins to be the first judicial intimation of the public rights doctrine. 66

[T] here are matters, involving public rights, which may be presented in such a form that the judicial power is capable of acting on them, and which are susceptible of judicial determination, but which congress may or may not bring within the cognizance of the courts of the United States, as it may deem proper. ${ }^{67}$

59. 430 U.S. 442, 453-56 (1977) (upholding Occupational Safety and Health Act of 1970, Pub. L. No. 91-596, 84 Stat. 1590 (codified as amended at 29 U.S.C. $\$ \S 651-678$ (1982))),

60. 430 U.S. at 450 .

The Court has never indicated, though, that it would consider a jury to be compatible with administrative adjudication, and one should not read the final clause in the Court's statement as such an indication.

61. Id. (footnote omitted) (einphasis added); see infra notes 149-65 and accompanying text.

62. Id. at $460-61$.

63. Kirst, Administrative Penalties and the Civil Jury: The Supreme Court's Assault on the Seventh Amendment, 126 U. PA. L. REV. 1281, 1287 (1978).

64. Atlas Roofing, 430 U.S. at 450-51 (citing Helvering v. Mitchell, 303 U.S. 391 (1938) (tax penalty); Lloyd Sabaudo Societa Anonima Per Azioni v. Elting, 287 U.S. 329 (1932) (customs and immigration penalty); Phillips v. Commissioner, 283 U.S. 589 (1931) (taxes); Oceanic Steam Navigation Co. v. Stranahan, 214 U.S. 320 (1909) (customs and immigration penalty); Murray's Lessee v. Hoboken Land \& Improvement Co., 59 U.S. (18 How.) 272 (1856) (tax recovery)); see also Kirst, supra note 63 , at 1287 n.30.

65. 59 U.S. (18 How.) 272 (1856).

66. See Northern Pipeline Constr. Co. v. Marathon Pipe Line Co., 458 U.S. 50, 67 (1982) (plurality opinion) (stating that public rights doctrine traces directly to Murray's Lessee).

67. Murray's Lessee, 59 U.S. (18 How.) at 284, quoted in Atlas Roofing, 430 U.S. at 451 n.8 (emphasis added). 
Justice White then reviewed five cases to develop the proposition that the seventh amendment does not prohibit Congress from delegating the adjudication of public rights to federal agencies. ${ }^{68} \mathrm{He}$ attempted to define public rights with only the following examples: "e.g., cases in which the Government sues in its sovereign capacity to enforce public rights created by statutes within the power of Congress to enact"69 or "e.g., where the Government is involved in its sovereign capacity under an otlerwise valid statute creating enforceable public rights."70 Although the Court strictly limited its holding to public riglits, in contradistinction to private rights, ${ }^{71}$ Atlas Roofing marks the Court's first use of the public rights doctrine to restrict the seventli amendment. ${ }^{72}$

\section{Article III Jurisprudence}

A comparison of the Supreme Court's seventh amendment jurisprudence with the Court's analysis of article III limits on congressional delegation of adjudicatory functions to administrative tribunals is important for several reasons. First, seventh amendment issues and article III issues may simultaneously arise in connection witl such delegations. Second, article III cases liave more fully developed the "public rights" theory that Atlas Roofing first imcorporated into seventh amendment jurisprudence. ${ }^{73}$ The public rights concept is in fact one part of the balancing test the Court has recently applied in reviewing Congress's delegation of adjudicatory functions to non-article III tribunals. ${ }^{74}$ Finally, the Court's article III jurisprudence may itself protect the riglit to a jury trial, eliminating the need for further protection under the seventh amendment.75

Article III, section 1 of the Constitution provides that the "judicial Power of the United States" will be vested in one Supreme Court and

68. Id. at $451-56$ (discussing Jones \& Laughlin; Curtis; Pernell; Block v. Hirsh, 256 U.S. 135 (1921), explained in Pernell, 416 U.S. at 382-83; Crowell v. Benson, 285 U.S. 22 (1932)).

69. Id. at 450 .

70. Id. at 458 (emphasis added). The use of the term "public rights" in its own definition reflects the Court's struggle with that concept. See infra notes 110-17 and accompanying text.

71. Id. at 458 ("Wholly private tort, contract, and property cases, as well as a vast range of other cases, are not at all implicated.").

72. Kirst, supra note 63, at 1287. Professor Kirst argues that the public rights rule had to be "created" to sustain the Atlas Roofing holding.

73. See generally Young, Public Rights and the Federal Judicial Power: From Murray's Lessee Through Crowell to Schor, 35 Buffalo L. Rev. 765 (1986) (extensive review of development of public rights in article III jurisprudence).

74. See infra notes 105-06 and accompanying text.

75. For a discussion of the development of the public rights doctrine and its effect on the jurisdiction of article III courts, see infra notes 83-109 and accompanying text. 
such lower federal courts as Congress establishes. ${ }^{76}$ Article III federal judges are appointed by the President "with the Advice and Consent of the Senate," 77 and enjoy life tenure and fixed compensation. ${ }^{78}$ While the language of article III suggests that Congress may only create lower courts staffed by judges with life tenure and fixed compensation, ${ }^{79}$ the Court has never interpreted the article so narrowly. ${ }^{80}$ The Court has recognized the authority of Congress to vest adjudicatory power in decisionmakers who are not guaranteed article III protections. ${ }^{81}$ The Court, however, has consistently refused to read article III so broadly as to provide Congress with plenary authority to create adjudicatory tribunals outside article III. ${ }^{82}$

\section{A. The Emergence of "Public Rights" Under Article III.}

Atlas Roofing was the first seventh amendment case to scrutinize the delegation of adjudicatory authority using the public rights/private rights distinction; in contrast, the Court has often relied on that distimction in defining the article III limits of congressional delegation. ${ }^{83}$ The distinction first arose in Murray's Lessee, ${ }^{84}$ in which the Court distinguished public rights, which are constitutionally delegable to non-article III courts, from claims in the nature of a suit at common law, in equity, or in admiralty, which are constitutionally nondelegable. Justice Curtis, writing for the Court, described matters involving public rights as subject to judicial determination, or, if Congress deems proper, equally subject to

76. U.S. CoNST. art. III, § 1 .

77. Id. art. II, § 2, cl. 2.

78. Id. art. III, §1.

79. See Northern Pipeline Constr. Co. v. Marathon Pipe Line Co., 458 U.S. 50,93 (1982) (White, J., dissenting).

80. See, e.g., id. at 70-71 (plurality opinion) (noting that exceptions to independent article III courts include courts outside the Uinted States, courts-martial, and forums dealing with public rights); American Ins. Co. v. Canter, 26 U.S. (1 Pet.) 511 (1828) (Marshall, C.J.) (upholding congressional power to use non-article III federal courts to adjudicate disputes in federal territories).

81. E.g., Crowell v. Benson, 285 U.S. 22 (1932) (approving determinations of fact by United States Einployees' Compensation Commission); see Resnik, The Mythic Meaning of Article III Courts, 56 U. CoLo. L. REv. 581, $582-83$ (1985).

82. See, e.g., Northern Pipeline, 458 U.S. at 50 ("We conclude that 28 U.S.C. $\$ 1471 \ldots$. has impermissibly removed most, if not ail, of 'the essential attributes of the judicial power' from the Art. III district court, and has vested those attributes iu a non-Art. III adjunct."); Resnik, supra note 81 , at 587 .

83. See Youug, supra note 73 , at 769 (noting that the public rights doctrine in article III jurisprudence traces back to 1855 and Murray's Lessee).

84. 59 U.S. (18 How.) 272 (1856); see Young, supra note 73, at 791-95 (discussion of public/ private rights distinction's origin). 
nonjudicial determination; he did not define public rights. ${ }^{85}$

As the adninistrative state began to flourish in the first half of the twentieth century, the Court faced new article III challenges to administrative adjudication. Crowell v. Benson, ${ }^{86}$ for example, involved the adjudication of a Longshoremen's and Harbor Workers' Compensation Act claim before the United States Employees' Compensation Cominission. ${ }^{87}$ Chief Justice Hughes cited Murray's Lessee to build on the distimction between private rights and "those which arise between the Government and persons subject to its authority im connection with the performance of the constitutional functions of the executive or legislative departnients." 88 Even though Crowell itself involved a "private right"- "the liability of one individual to another under the law" - ${ }^{89}$ the Court there upheld Congress's ability to assign factfinding functions to an administrative forum, analogizing the role of agencies to the role of inasters or assessors in equity and admiralty. ${ }^{90}$ Because the coinpensation statute applied only to a limited class of master and servant cases, and its effective enforcement required only determinations of factual questions, the Court found no constitutional obstacle to the assignment of the "thousands of cases" under the statute to the administrative agency.91

In 1982, the public rights doctrime reached its zenith in Northern Pipeline Construction Co. v. Marathon Pipe Line Co. The Court held that Congress's broad grant of jurisdiction to the bankruptcy courts violated article III. ${ }^{92}$ Writing for a plurality, Justice Brennan noted that public rights cases were an exception to the jurisdiction of article III courts. ${ }^{93}$ He then described public rights as extending "only to matters arising "be-

85. Murray's Lessee, 59 U.S. (18 How.) at 284. Justice Curtis did no more than provide an example of a public right that Congress could subject to nonjudicial determination: equitable claims to land by inhabitants of ceded territories.

86. 285 U.S. 22 (1932).

87. Id. at 36 .

88. Id. at 50 .

89. Id. at 51 .

90. Id. The Court quickly disposed of a seventh amendment objection, stating that the suit was not one at common law, but rather a suit that, in the absence of the statutory scheme, would have been within adıniralty jurisdiction. Id. at 45 .

91. Id. at 54 .

92. 458 U.S. 50, 87 (1982) (plurality opinion); id. at 91-92 (Rehnquist \& O'Connor, JJ., concurring).

Article III and seventh amendnient issues continue to arise in the bankruptcy context. See generally Gibson, Jury Trials in Bankruptcy: Obeying the Commands of Article III and the Seventh Amendment, 72 MINN. L. REv. 967 (1988) (arguing that jury trial rights exist for some bankruptcy matters and that seventh amendment and article III questions can be resolved by conducting such trials before article III district judges). The Court may define a seventh amendment limit this Term in Nordberg v. Granfinanciera, S.A. (In re Chase \& Sanborn Corp.), 835 F.2d 1341 (11th Cir. 1988), cert. granted, 108 S. Ct. 2818 (1988).

93. Northern Pipeline, 458 U.S. at 67-70. 
tween the Government and persons subject to its authority in connection with the performance of the constitutional functions of the executive or legislative departınents,' and ouly to matters that historically could have been determined exclusively by those departments." 94 Unwilling to clarify the inuddled distimction between public and private rights, the plurality would ouly say that public rights "Inust at a minimum arise "between the government and others," "95 and that private rights involve " "the hability of one individual to another under the law." "96

\section{B. The Retreat from "Public Rights" Under Article III.}

Three years later, the Court retreated froin Justice Brennan's view of the public rights doctrine. In Thomas v. Union Carbide Agricultural Products Co., ${ }^{97}$ the Court noted that only a plurality in Northern Pipeline had concluded that the public riglits doctrine provided a bright-line test. Justice O'Connor, writing for the Union Carbide inajority, then rejected the argument that the right to an article III fornm is absolute unless the federal government is a party of record; she recognized that acceptimg that argument wonld cast doubt on the constitutionality of much of the administrative state. 98 The Union Carbide Court saw the public rights doctrime as "a pragmatic understanding that when Congress selects a quasi-judicial metlod of resolving matters that 'could be conclusively determined by the Executive and Legislative Branches,' the danger of encroaching on the judicial powers is reduced." 99

Justice Brennan, in his concurrence, declined to reject his Northern

94. Id. at 67-68 (citation omitted). Justice Brennan, however, refrained from defining public rights or private rights. Id. at 69 .

95. Id. (quoting Ex parte Bakehte Corp., 279 U.S. 438, 451 (1929)). The plurality again cited Murray's Lessee for the distinction between suits that by their "nature" were suits at common law, equity, or admiralty, and those that could be withdrawn from the cognizance of article III courts because they involved public rights. Id. at 69 n.23. Justice Brennan added that the presence of the Uinted States as a proper party to the proceeding was a "necessary but not sufficient means of distinguishing 'public rights' from "private rights'." Id.

96. Id. at $69-70$ (quoting Crowell, 285 U.S. at 51).

97. 473 U.S. 568,584 (1985).

98. Id. at 585-87.

99. Id. at 589 (quoting Northern Pipeline, 458 U.S. at 68).

Despite its disavowal of the importance of the public rights doctrine in article III jurisprudence, the Union Carbide Court did describe the statutory scheme passed by Congress as bearing many of the characteristics of a public right. 473 U.S. at 589 . The dispute involved private parties at odds over payments for the use of research data as inandated by the Federal Insecticide, Fungicide, and Rodenticide Act. See id. at 575-78. The Act provides for binding arbitration of disputes arising between a registrant who has submitted research data on its products' health and safety characteristics to the EPA as required under the Act, and a follow-on registrant who is required to compensate the prior registrant for the use of the original data. Id. at 571-73. The Court recognized that Congress had set up an extensive program to proteet the public health and that "[u]se of a registrant's data to support a follow-on registration serves a public purpose." Id. at 589. 
Pipeline view of the public rights doctrine. ${ }^{100} \mathrm{He}$ agreed with the majority that the presence or absence of the government as a party is not the determinative factor in defining public rights cases, but emphasized that, even though the case involved the determination of rights owed one private party by another, the dispute arose "im the context of a federal regulatory scheme that virtually occupies the field." $101 \mathrm{He}$ agreed with Congress's decision that the public pohicies underlying the comprehensive regulatory scheme required arbitration and thus justified the federal agency's active participation in resolving the private dispute. ${ }^{102}$

In 1986, the Court again rejected an article III challenge to administrative adjudication in Commodity Futures Trading Commission v. Schor. ${ }^{103}$ Writing for the Court once agam, Justice O'Connor described article III's purpose as protecting both the judiciary's independent role im the constitutional scheme of separation of powers and imdividual litigants' right to an independent judiciary. ${ }^{104}$ Based on this underlying purpose, as well as the view that formalistic, bright-line rules would be too restrictive and unworkable for Congress, ${ }^{105}$ the Court outlined a four-part balancing test for evaluatimg the constitutionality of adjudication in a non-article III forum: (1) the extent to which the statutory scheme reserves the essential attributes of judicial power for article III courts; (2) the extent to which the non-article III forum exercises the jurisdiction and powers normally vested in article III courts; (3) the concerns that drove Congress to depart from the requirements of article III; and (4) the origins and importance of the right to be adjudicated in the non-article III forum. ${ }^{106}$

Acknowledging that Schor involved a private right, ${ }^{107}$ the Court applied Union Carbide and held that the public rights doctrine only reflects

In the end, the Court sustained the Act, but limited its holding to cases involving private rights "so closely integrated into a public regulatory scheine as to be a matter appropriate for agency resolution with limited involvement by the Article III judiciary." Id. at 593-94.

100. Id. at 600 ("Because the approach of the plurality opinion in Northerm Pipeline is suffciently flexible to accounmodate the demands of contemporary government while preserving the constitutional system of checks and balances, I adhere to it as the proper analysis for resolving the present case.") (Brennan, J., concurring, joined by Marshall \& Blackmun, JJ.).

101. Id.

102. $I d$.

103. 478 U.S. 833 (1980).

104. Id. at $847-49$.

105. Id. at 851 ("Although such rules might lend a greater degree of coherence to this area of the law, they might also unduly constrict Congress' ability to take needed and innovative action pursuant to its article I powers.").

106. Id. at 853 .

107. Id. at $837-38,853$. The private right involved was a state-law counterclaim for a debt owed to a commodities dealer. 
pragmatic considerations and is not determinative in article III cases. ${ }^{108}$ As the Court also noted, the Constitution does not forbid Congress to divest the article III courts of jurisdiction over private right claims that are necessary to ensure the effectiveness of a regulatory scheme. ${ }^{109}$

\section{The CurRent CONFUSION-Public RightS AND PRIVATE RIGHTS}

The first step in determining whetler the Court lias established a seventh amendment, as opposed to an article III, limit on Congress's authority to delegate adjudicatory responsibility is to reevaluate the stature of the public rights exception established in Atlas Roofing. ${ }^{110}$ As an initial concern, the Court has offered no firm definition of public rights in either seventli amendment or article III cases. In the article III context, the public rights doctrine, as origmally articulated in Murray's Lessee and Crowell, had some structure. There the Court apparently limited the doctrine to disputes between the government and private parties over the perfornance of legislative or executive obhigations.111 Public rights cases were thus distinguishable froin suits at common law, which the Court in Murray's Lessee said could not be withdrawn from article III courts' jurisdiction. ${ }^{112}$ Atlas Roofing incorporated this public rights exception into seventh amendment jurisprudence. ${ }^{113}$

In the wake of Union Carbide and Schor, however, the definition of public rights has devolved into near-tautology. Public rights, according to the Court's current formulation, are matters that the executive and legislative branches can conclusively determine. ${ }^{114}$ But what can those branches not conclusively determine? The line between public and private rights lias blurred, at least where Congress has integrated the private right at issue into a statutory scheme. ${ }^{115}$ More importantly, the distimction first drawn in Murray's Lessee-between public rights and suits at common law-is no longer determinative. Although the Schor opinion

108. Id. at 853-54; see also supra notes $98-99$ and accompanying text (discussing Union Carbide's "pragmatic understanding" observation).

109. Id. at 853-57. Applying this analysis, the Court upheld the Commodity Futures Trading Commission's jurisdiction over state-law counterclaims.

110. See supra notes $59-71$ and accompanying text.

111. See Crowell v. Benson, 285 U.S. 22, 50 (1932) (citing Murray's Lessee v. Hoboken Land \& Improvement Co., 59 U.S. (18 How.) 272, 284 (1856)).

112. 59 U.S. (18 How.) at 284.

113. 430 U.S. 442, 450 (1977) ("At least in cases in which 'public rights' are being litigated . . . the Seventh Amendinent does not prohibit Congress from assigning the factfinding function and initial adjudication to an administrative forum with which the jury would be inconpatible.").

114. Commodity Futures Trading Comm'n v. Schor, 478 U.S. 833, 853-54 (1986).

115. See Thomas v. Union Carbide Agric. Prods. Co., 473 U.S. 568, 593-94 (1985); see also supra notes $97-99$ and accompanying text. 
cited Murray's Lessee, the Court wonld guarantee only "searching" review under article III in cases "where private, common law rights are at stake."116 Moreover, in performing this searching review, the Court adopted a "de minimis" test, allowing minor intrusions into the private rights jurisdiction of the federal courts. ${ }^{117}$

If the importance of the public rights doctrine has faded in article III jurisprudence, the Supreme Court will likely give the doctrine even less credence in the context of seventh amendinent jury trial challenges. Even as the public rights exception reached its zenith in Northern Pipeline, Justice White, five years after his seventh amendment opinion in Atlas Roofing, indicated in dissent his behef that the public rights doctrine had already received its "death blow" in Crowell, which permitted a factfinding role for agencies in matters that involve private rights. ${ }^{118}$ After Union Carbide and the development of the Schor balancing test, the public rights/private rights distinction no longer serves as a bright-line test in any context. ${ }^{119}$

The Court has long recognized the link between article III and the seventh amendment, ${ }^{120}$ and recent article III developnients raise the question whether the public rights doctrine survives at all as a constitutional theory in the seventh amendment context. The Court's rehance in Atlas Roofing on cases primarily concerued with an article III objection suggests a decline in the doctrine's importance. ${ }^{121}$ The doctrine's devaluation in the article III cases does not, however, compel the conclusion that public rights theory has lost all of its force in seventh amendment cases.

The article III cases that deeinphasize public rights are distimguishable from the seventh amendment cases. According to Schor, article III protects both institutional (separation of powers) concerns and individual hitigants' rights. ${ }^{122}$ In contrast, the purpose of the seventh amendment is

116. Schor, 478 U.S. at 854 .

117. Id. at 856-57.

118. Northern Pipeline Constr. Co. v. Marathon Pipe Line Co., 458 U.S. 50, 109-10 (1982) (White, J., dissenting).

119. See Schor, 478 U.S. at 853; Union Carbide, 473 U.S. at 585-86.

120. See supra note 23 and accompanying text.

121. See Atlas Roofing Co. v. Occupational Safety \& Health Review Comm'n, 430 U.S. 442, 450-52 (1977) (discussing Crowell v. Benson, 285 U.S. 22 (1932); Murray's Lessee v. Hoboken Land \& Inprovement Co., 59 U.S. (18 How.) 272 (1850)). In Murray's Lessee, a seventh amendment objection was raised but never discussed by the Court. The Crowell Court disposed of the seventh amendinent objection on the grounds that the case was within the admiralty jurisdiction. 285 U.S. at 45.

122. Schor, 478 U.S. at 848. 
solely the protection of individuals. ${ }^{123}$ The Schor Court found that the individual litigant had waived his right to an article III trial by demanding that the administrative tribunal decide his state-law claim. ${ }^{124}$ The Court's public riglits analysis, therefore, arguably reflects only article III institutional concerns. ${ }^{125}$ Notwithstanding its article III implications, Schor need not sigual the erosion of the public riglits doctrine in the seventh amendment context.

\section{The Practical Considerations favoring Judicial RESTRAINT IN THE FACE OF CONGRESSIONAL ACTION}

Assuming for the sake of discussion that the public rights doctrine no longer restricts Congress's ability to delegate adjudicatory power to administative agencies, no seventh amendment check on congressional overreaching exists. Congress in fact continues to define new statutory riglits and to provide for agency adjudication of those rights, ${ }^{126}$ and the Court so far has deferred to Congress's delegations of adjudicatory authority.

The current uncertainty about the seventh amendment limitations on agency determinations may reflect the Court's view that Congress has not yet breached those limitations. The Court has never held that an administrative tribunal inay adjudicate a purely private right witlout a jury trial. ${ }^{127}$ The Court, after all, declines to answer unnecessary constitutional questions. ${ }^{128}$ Understanding the seventh amendment precedents first requires an examination of the Court's rationale for deferring to Congress.

The Court has cited several practical considerations supporting administrative adjudication; some of these factors explam the Court's defer-

123. See, e.g., Jacob v. New York City, 315 U.S. 752, 752-53 (1942) (citizens' fundamental and sacred right to jury trial is protected by seventh amendment); Wolfram, supra note 15, at $646 \mathrm{n} .21$ (seventh amendment is not rule of mere judicial administration, but of personal protection to litigants).

124. Schor, 478 U.S. at 849.

125. This analysis, lowever, is hard to reconcile with the Court's discussion of private rights. Id. at 853-54.

126. See Comment, The Constitutional Rights to Trial by Jury and Administrative Imposition of Money Penalties, 1976 DuKE L.J. 723, 724 (Congress has granted an increasing number of agencies statutory authority to issue monetary penalties, subject to only limited judicial review); see also $\mathrm{S}$. 558, 100tl Cong., 1st Sess., 133 CoNG. REc. S2256 (daily ed. Feb. 19, 1987) (amendinents to Fair Housing Act providimg for new administrative enforcement mechanisin).

127. See Atlas Roofing Co. v. Occupational Safety \& Health Review Comm'n, 430 U.S. 442, 457-58 (1977) (right to jury trials in "[w]holly private tort, contract, and property cases" has not been destroyed by the Court's precedents).

128. See, e.g., Nortliern Pipeline Constr. Co. v. Marathon Pipe Line Co., 458 U.S. 50, 90 (1982) (Rehnquist, J., concurring) (Court will not anticipate questions of constitutional law and decide them before properly presented). 
ence. First, the administrative bureaucracy is so pervasive that newly created restrictions on Congress's authority could jeopardize the constitutionahty of large segments of that bureaucracy ${ }^{129}$-a legitimate consideration when the Court considers the scope of constitutionally protected individual rights. ${ }^{130}$

The Court's deference to congressional decisions to withdraw the determination of statutory rights from the judicial branch may also reflect institutional self-preservation. The courts have only a limited capacity to deal with the overwhelming number and technical complexity of cases now adjudicated im agencies. ${ }^{131}$ As Justice White stated in Atlas Roofing: "Congress is not required by the Seventh Amendment to choke the already crowded federal courts with new types of litigation . ..."132 He thus praised the "speedy and expert resolution[ ] of the issues" in agency adjudication. ${ }^{133}$

The Court's tendency to respect congressional determinations of the appropriate adjudicatory forum also reflects a perception of the "functional limitations" of juries. Commentators have suggested, ${ }^{134}$ and the Court in Ross v. Bernard has apparently acknowledged, ${ }^{135}$ that the pre-

129. See Northern Pipeline, 458 U.S. at 113. As Justice White stated in dissent:

Unless we want to overrule a large number of our precedents upholding a variety of Art. I courts-not to speak of those Art. I courts that go by the contemporary name of "adminstrative agencies"- this conclusion is inevitable. It is too late to go back that far; too late to return to the simplicity of the principle pronounced in Art. III and defended so vigorId. ously and persuasively by Hamilton in The Federalist ....

130. Individual rights are not absolute. Fundamental riglits such as privacy in clildbearing unay be restricted by Congress if necessary to proinote a "coinpelling" government interest. See, e.g., P. Brest \& S. Levinson, Processes of Constitutional Decisionmaking: CASes and MateriALs 673 (2d ed. 1983) (quoting Justice Brennan's opinion in Carey v. Population Servs. Int'l, 431 U.S. 678, 686 (1977), concerning state regulation of contraception). Specific Bill of Rights guarantees may also be restricted. See, eg., FCC v. Pacifica Found., 438 U.S. 726, 728-29 (1978) (broadcaster's first amendment riglits restricted). Unlike most other Bill of Riglits guarantees, the seventh amendment riglit to jury trial has not been leld "fundamental," and thus is not applied to the states through the fourteenth amendment's due process clause. See Walker v. Sauvinet, 92 U.S. 90,92 (1876).

131. See Crowell v. Benson, 285 U.S. 22, 54 (1932) (agency adjudications necessary to apply and enforce regulations in the "thousands of cases involved"); Fallon, supra note 1, at 953 (outlining several limitations on federal judiciary in a highly regulated modern society and noting that "[t]o require initial judicial resolution of all disputes would place an overwhelning burden on courts and litigants that our tradition sensibly has sought to avoid.").

132. Atlas Roofing, 430 U.S. at 455.

133. Id. at 461 .

134. See, e.g., Arnold, A Historical Inquiry Into the Right to Trial by Jury in Complex Civil Litigation, 128 U. PA. L. REv. 829, 829-30 (1980); Comment, The Right to Trial by Jury: Old English Law Supports a Complexity Exception to the Seventh Amendment, 11 SETON HALL L. Rev. 31, 31-34 (1980).

135. 396 U.S. 531, 538 n.10 (1970). Footnote 10 in Ross lias engendered prolific commentary in the law journals and in the lower courts. The Court in Ross indicated that the "practical abilities 
sumed "practical" shortcomings of lay juries may restrict the right to a jury trial. This functionalist argument, however, has hittle historical support. ${ }^{136}$ The Framers recognized that at least one function of the seventh amendment was to protect individual hitigants against corrupt judges; now, however, a litigant may be entitled to a jury trial before a judge insulated by article III's protections, but not before administrative adjudicators unprotected by article III. ${ }^{137}$ Moreover, the idea of rejecting a constitutional guarantee as too burdensome is inconsistent with the Framers' views, and the Court's modern Bill of Rights jurisprudence. ${ }^{138}$ The functionalist argument, then, seems a weak rationale for deference to Congress's forum choices.

Straightforward poitical considerations provide a stronger rationale. Elected representatives are presumably sensitive to the value that the general population places on the right to trial by jury. Thus, Congress is unlikely to expand the administrative state to the point of effectively eliminating that right in civil cases. ${ }^{139}$ Viewed in this context, the Court's failure to articulate a definitive seventh amendment limit may create an uncertainty desirable to the most ardent proponents of the right to a jury trial. Congress, fearing the wrath of both the public and the

and limitations of juries" was one factor that courts could consider in determining the nature of an issue and the applicability of the seventh amendment. The Court lias applied this functionalist approach only in the context of administrative adjudication, "with which the jury would be incoinpatible." Atlas Roofing, 430 U.S. at 450; see also Tull v. United States, 107 S. Ct. 1831, 1835 n.4 (1987) (considering practical limitations of juries).

136. See Wolfram, supra note 15, at $742 \mathrm{n} .304$ (noting that at time of the seventh amendinent, Peunsylvania and Connecticut provided right to jury trial in virtually all civil cases, but that Alexander Hamilton opposed jury trials in equity courts "because it would necessitate the trial by jury of "questions too complicated for a decision in that inode" " (quoting The FEDERALIST No, 83, at 570 (A. Hamilton) (J. Cooke ed. 1961))).

137. See id. at 653; see also Redish \& Marshall, Adjudicatory Independence and the Values of Procedural Due Process, 95 YALE L.J. 455, 499 (1986) ("Evidence suggests that various agencies have used the possibility of renoval as a tool for coercing decisions that are consistent with the agency's wishes.").

138. Wolfran, supra note 15 , at 648 n.33.

Different theories of constitutional interpretation lave been identified and accepted as legitiniate. Professor Fallon addresses the "coniniensurability problein" inherent when the different theories are applied in a specific constitutional context by proposing a "constructivist coherence theory." Fallon, A Constructivist Coherence Theory of Constitutional Interpretation, 100 HARV. L. REV. 1189 (1987). Professor Fallon argues that the different interpretative theories are substantially interrelated and interdependent; the constitutional interpreter therefore can usually achieve a "constructivist coherence" that answers the constitutional question. Id. at 1193. That different theories of constitutional interpretation lead to the conclusion that the right to a jury trial cannot be elininated siniply on "functionalist" grounds is consistent with Professor Fallon's inodel.

139. See Hart, The Power of Congress to Limit the Jurisdiction of Federal Courts: An Exercise in Dialectic, 66 HARV. L. REv. 1362, 1365 (1953) ("Congress so far has never tried to destroy the Constitution."). But cf. Barrett, The Constitutional Right to Jury Trial: A Historical Exception for Small Monetary Claims, 39 HASTiNGs L.J. 125, 148 (1987) (1794 Pennsylvania statute diminished right to jury trial as it existed when state's constitution was adopted). 
courts, has a powerful incentive to act prudently when vesting agencies with expansive authority. ${ }^{140}$ Congress might even find it pohitically appealing to provide a right to a jury trial where none is constitutionally required. ${ }^{141}$

Political restrictions in fact sealed the fate of Senate bill 558, legislation that would have restricted the scope of tlie seventli amendment. The bill would have ainended the enforceinent provisions of prior fair lousing legislation to allow a party charging discriminatory lousing practices to seek dainages eitlier before an administrative law judge (ALJ) or in federal court, witl review in the circuit courts of appeals. ${ }^{142}$ The consensus of acadeunic opinion voiced before the Senate Subcommittee on tlie Judiciary was that the Senate bill would be constitutional under the Supreme Court's seventl amendment jurisprudence. ${ }^{143}$ Compromise legislation eliminating inandatory administrative adjudication was proposed, however, and eventually passed after opponents objected to S. 558's encroaclıment on jury trial riglits. ${ }^{144}$ As the Court defines the ultimate

140. See Northern Pipeline, 458 U.S. at 87.

141. See 5 J. MooRE, supra note 18, \ 38.08[5.-4] ("There is nothing in the Seventh Amendinent nor in Article III that precludes Congress froin extending the right of jury trial to non-common law actions, $\ldots$ although as a general proposition it has not seen fit to do so.").

142. S. 558, 100th Cong., 1st Sess., 133 CoNG. Rec. S2259 (daily ed. Feb. 19, 1987).

143. The Subcommittee on the Constitution will issue no report concerning the constitutionality of S. 558. Professors Thomas Rowe of Duke, Girardeau Spann of Georgetown, and Arthur Wolf of Western New England College testified before the Subcommittee and concluded that the enforcement provisions of $S .558$ did not violate the seventh amendment. Telephone interview with staff members of Subcommittee on the Constitution (Sept. 13, 1988).

144. The bill was referred to the Senate Judiciary Committee on February 19, 1987, and hearings were held by the Subcommittee on the Constitution. [1987-1988] 1 Cong. Index (CCH) 21,008. On June 23, 1987, the Subcommittee approved S. 558 by a four-to-one vote. 45 CoNG. Q. WEekLY REP. 3227 (1987). The Supreme Court confirmation battles involving Judges Bork, Ginsburg and Kennedy stalled action by the Senate Judiciary Committee for a considerable time. Id. A House counterpart bill, H.R. 1158, was approved by the House Judiciary Committee on April 27, 1988, but received strong Republican opposition because the bill proposed to allow an administative law judge to levy fines against alleged housing discriminators without the benefit of a jury trial. See Fair Housing Bill Approved by House Judiciary Committee, 46 CONG. Q. WeEkLY REP. 1159 (1988). The House overwhelmingly passed H.R. 1158 on June 29, 1988. See Prognosis Good as Housing Bill Goes to Senate, 46 CONG. Q. WeEkLY REP. 1838 (1988).

The Senate passed a compromise version of H.R. 1158, eliminating the inandatory administrative adjudication. See Backed by Reagan, Senate OKs Fair-Housing Law, 46 CONG. Q. WeEkLY REP. 2203 (1988). Under the compromise bill, an alleged housing discriminator, notified by the Secretary of Housing and Urban Development of an action pending against him, may choose between the administrative forum or federal court. Id. The amendment defused the President's seventh amendment objections to past versions of the bill. Id. The Senate version of H.R. 1158 was sent to the House, which approved the compromise measure by voice vote on August 8, 1988. [1987-1988] 2 Cong. Index (CCH) 34,101. President Reagan signed the compromise version of H.R. 1158, with its choice-of-forum provision, on September 13, 1988. See 24 WeEkLy Comp. Pres. Doc. - (Sept. 19, 1988). This note uses the original version of S. 558 to illustrate seventh amendment issues raised by congressional attempts to mandate administrative adjudication. 
scope of the seventh amendment, its deference to Congress surely reflects an awareness of the dynamics of the democratic political model.

Deference to Congress, however, is not absolute and must yield when the Court faces a clear constitutional command. ${ }^{145}$ A primary objection to the Constitution concerned the Framers' failure to provide a right to civil jury trial. ${ }^{146}$ That objection echoed the colonists' outcry when the jurisdiction of a nonjury forum-the vice-admiralty courtwas expanded under English rule. ${ }^{147}$ As the Court recognized in Curtis v. Loether, and now needs to reaffirm, practical policy considerations are "insufficient to overcoine the clear command of the Seventh Amendnient." 148

\section{RETHINKING ATLAS ROOFING}

\section{A. Forum-Dependent Analysis.}

Atlas Roofing illustrated the Suprene Court's reluctance to invalidate, in the context of a seventh amendment attack, an administrative scheme conferring broad enforcement powers. The Court reviewed the Occupational Health and Safety Act of 1970, which allows the Occupational Health and Safety Administration to impose civil penalties on violators and collect those penalties in federal court. ${ }^{149}$ The Court upheld the Act against the seventh ainendment challenge, but limited its lolding to cases involving public rights. Commentators initially criticized the Court's use of the public rights doctrine as a deviation from the historical test. ${ }^{150}$ This criticism, as well as the Court's subsequent deemphasis of the public rights doctrine in article III cases indicates the need to consider alternate justifications for the Atlas Roofing decision.

One plausible justification for the Atlas Roofing decision is that the seventl amendment simply does not apply to administrative proceedings, because they are technically not suits at common law. ${ }^{151}$ This forun1-

145. See, e.g., Northern Pipeline, 458 U.S. at 73 (portion of Bankruptcy Act of 1978 threatened "to supplant completely our system of adjudication in independent Art. III tribunals").

146. See Wolfram, supra note 15, at 657 (noting that entire discussion in Constitutional Convention on lack of a Bill of Rights was sparked by question on right to jury trial). Wolfram's article documents the historical background of the seventh amendment.

147. See Note, supra note 52, at 1465 n.34 ("British use of vice-admiralty courts to deprive colonists of their rights to jury trial was one of the inost disliked aspects of English rule.").

148. 415 U.S. 189, 198 (1974); see also Redish, supra note 24, at 521.

149. See, e.g., Pub. L. No. 91-596, § 17, 84 Stat. 1590, 1606 (1970) (codified as amended at 29 U.S.C. $\S 666$ (1982)).

150. See, eg., Kirst, supra note 63, at 1293-311 (arguing that there really is no public rights exception).

151. See NLRB v. Jones \& Laughlin Steel Corp., 301 U.S. 1, 48 (1937) ("The instant case is not a suit at common law or in the nature of such a suit. . . It is a statutory proceeding."); F. JAMES \& G. HAZARD, supra note $53, \S 8.11$, at $450-51$. 
dependent analysis does have historical support, as the Atlas Roofing Court noted, ${ }^{152}$ since the pre-1791 right to a jury trial turned on the forum in which a suit was tried-a law court or an equity court. ${ }^{153}$ A pure forum-dependent analysis, however, ignores the Court's consistent rulings that the jurisdiction of equity (and admiralty) is not unlimited, but is confined by the seventh amendment. ${ }^{154}$ Unless either the seventh amendment or article III limits Congress's ability to delegate adjudicatory authority to administrative agencies, the agencies' decisionmaking power seems potentially limitless, confined only by Congress's sense of selfrestraint. ${ }^{155}$

Pure forum-dependent analysis also runs counter to the Court's consistent interpretation of the seventh amendment. Since Parsons v. Bedford, the Court has maintained that the seventh amendment protects the right to jury trial when legal rights are at issue. ${ }^{156}$ The seventh amendment applies to common law suits involving legal rights-not to common law courts. 157

It has been argned that the Court could resolve the inconsistency between its seventh amendment jurisprudence and the forum-dependent doctrine by simply holding that statutory actions are not suits at common law. ${ }^{158}$ Such an argument suggests, however, that no right to jury trial exists in statutory actions adjudicated before either a federal court or an administrative agency-and the Court has clearly held that statutory actions can be suits at common law witlim the meaning of the seventh amendment. ${ }^{159}$ The argument that statutory actions are not suits at

Similar arguments arise in the bankruptcy context. Some authorities assert that no constitutional right to a jury trial exists in any bankruptcy matter because bankruptcy courts are traditionally considered courts of equity. See Gibson, supra note 112, at 1004 \& nn.172-73. Professor Gibson, however, argues that a legal claim is not "magically transformed" imto an equitable one merely because it is asserted in bankruptcy court. Id. at 1018. Although bankruptcy adjudication is distinguishable froin agency adjudication, see id. at 1024-25, the abridgment of a constitutional right, based on such a simple rationale, is inappropriate in both contexts.

152. Atlas Roofing Co. v. Occupational Safety \& Health Review Comm'n, 430 U.S. 442, 458-61 (1977) (discussing precedent to support proposition that seventh amendment right to jury trial depends on forum in which action is brought).

153. See supra notes $18-21$ and accompanying text.

154. See 5 J. Moore, supra note 18, I 38.08[5.-4].

155. See, e.g., Northern Pipeline Constr. Co. v. Marathon Pipe Line Co., 458 U.S. 50 (1982) (plurality opinion) (using article III to strike down provision in Bankruptcy Act that shifted too much adjudicatory authority froin federal judiciary to article I courts).

156. 28 U.S. (3 Pet.) 433, 446-47 (1830).

157. See Redish, supra note 24, at 519-20 (Justicc Story's opinion in Parsons suggests that right to jury trial could extend to adininistrative proceedings).

158. See Note, supra note 52, at 1459-60.

159. Curtis v. Loether, 415 U.S. 189, 194 (1974) ("The Seventh Amendment does apply to actions enforcing statutory rights, and requires a jury trial upon demand, if the statute creates legal 
common law also clashes with the historical test ${ }^{160}$ and, arguably, with constitutional theories that consider changing social conditions in imterpreting the Constitution. ${ }^{161}$

Significantly, the Atlas Roofing Court relied on article III precedents in establishing a seventh amendment public rights limitation on Congress's discretion to delegate adjudicatory authority. ${ }^{162}$ Atlas Roofing imphes that the Court's article III analysis will adequately protect seventh amendment concerns. Given the close relationship between the seventh amendment and article III, ${ }^{163}$ Schor's article III balancing test ${ }^{164}$ may sufficiently protect the seventh amendment right to trial by jury. ${ }^{165}$

\section{B. Atlas Roofing and Schor.}

A hypothetical congressional enactment illustrates how the Schor test might apply. Assume that Congress, acting under the commerce clause, ${ }^{166}$ decides to estabhisl a national fare structure for all taxicabs servicing airports. As the legislative history indicates, Congress has found that fare disputes between drivers and passengers present a major problem; it expects the filing of a large number of cases under the statute. The federal statute regulates only fares; it does not regulate such things as driver hicensing requireinents, scheduling, or taxi safety. The legislation provides that the Department of Transportation will adjudicate all fare disputes before an ALJ in an "on-the-record" proceeding. ${ }^{167}$ Parties may appeal decisions to the Secretary of Transportation and then to the United States Court of Appeals for the District of Columbia Circuit or the circuit in which their case arose. The Administrative Procedure Act governs the scope of review in the courts of appeals. ${ }^{168}$

rights and reinedies, enforceable in an action for damages in the ordinary courts of law."); see supra notes 24-28 and accompanying text.

160. Statutory actions could be adjudicated in common law courts. See, e.g., Pernell v. Southall Realty, 416 U.S. 363,379 (1974) (during reign of Henry VI, jury trials were available in actions to rccover possession of property under forceable entry and detainer statute).

161. See Redish, supra note 24, at 487 ("Ever since Chief Justice Marshall admonished that it is a constitution we are expounding' ' courts generally have been willing to read the broad language of the Constitution to account for changing social conditions.") (footnote omitted).

162. See supra notes $59-71$ and accompanying text.

163. See supra notes 24 and accompanying text.

164. See supra notes $105-06$ and accompanying text.

165. Cf. Note, supra note 52, at $1473 \mathrm{n} .81$ ("[I]f Article III does not require adjudication of the action in an Article III tribunal, the action cannot be a 'suit at common law' for seventh amendment purposes.").

166. U.S. CoNST. art. $1, \S 8, \mathrm{cl} .3$.

167. See Administrative Procedure Act, 5 U.S.C. $\S 554$ (1982) (on-the-record agency adjudications).

168. See id. $\S 706$. Under the Administrative Procedure Act, "the reviewing court shall decide all relevant questions of law." The agency's findings in the hypothetical would be set aside if "un- 
The four-part Schor balancing test may allow administrative adjudication under the hypothetical statute. First, because judicial review is available in the court of appeals, the statutory scheme arguably reserves the essential attributes of judicial power to article III courts. ${ }^{169}$ Second, the ALJs have no ancillary jurisdiction and are vested with only the limited powers necessary for agency adjudication, not the broad powers of article III judges. ${ }^{170}$ Third, the Court has been consistently sympathetic to Congress's atteinpts to provide efficient, expedient adjudication of a large nuunber of cases without burdening the federal courts. ${ }^{171}$ Under Schor's fourth factor, however, fare disputes between passengers and drivers clearly involve private rights not closely integrated into a pervasive regulatory scheine.

The Schor balance suggests that the hypothetical statute would pass article III constitutional muster as only a de minimis infringement of the judiciary's constitutional role. ${ }^{172}$ The Court has said that no single factor is determinative, ${ }^{173}$ and the Court has relegated the public rights doctrine to the status of a "pragmatic understanding." 174 More importantly, the Court no longer recognizes the nltimate distinction between public rights and "suits at common law."175 Thus, the weight of the Schor factors, pragmatic considerations, ${ }^{176}$ and recent precedent support the conclusion that the hypothetical statute does not violate article III.

If the Court were to face a congressional statute similar to this hypo-

supported by substantial evidence." Id. §706(2)(E); see id. §556 (section applies to $\S 554$ "on the record" proceedings).

169. See Commodity Futures Trading Comm'n v. Schor, 478 U.S. 833, 853 (1986) (article III courts review CFTC orders under "weight of the evidence" standard and legal rulings under de novo standard); cf. Thomas v. Union Carbide Agric. Prods. Co., 473 U.S. 568, 573-74, 592 (1985) (limited judicial review of arbitrator's decision by article III court).

170. Cf. Nortliem Pipeline Constr. Co. v. Marathon Pipe Lime Co., 458 U.S. 50, 5455 (1982) (plurality opinion) (bankruptcy judges had impermissibly broad jurisdiction and powers).

171. See Crowell v. Benson, 285 U.S. 22, 54 (1932) (administrative adjudication relieves courts of serious burden, preserves courts' authority to ensure proper application of law, and makes application of law in large nuniber of cases possible); see also Atlas Roofing Co. v. Occupational Safety \& Healtli Review Comm'n, 430 U.S. 442, 455 (1977) ("Congress is not required by the Seventh Amendment to clroke the already crowded federal courts with new types of litigation or prevented from conumitting some new types of litigation to administrative agencies with special conpetence in the relevant field.").

172. See Schor, 478 U.S. at $851-52$ ("the congressional sclieme does not impermissibly intrude on the province of the judiciary").

173. Id. at 851 .

174. Id. at 853 (quoting Thomas v. Union Carbide Agric. Prods. Co., 473 U.S. 568,589 (1985)); see supra notes $99,107.08$ and accompanying text.

175. Schor, 478 U.S. at 854 ; see supra notes $116-17$ and accompanying text.

176. For a discussion of the practical considerations that favor judicial restraint in the face of congressional action, see supra notes $126-41$ and acconipanying text. 
thetical one, the Court could hold that the statute satisfies article III ${ }^{177}$ but violates the seventh amendment. When Congress creates a new statutory right, it has substantial discretion to prescribe the manner of the right's adjudication, ${ }^{178}$ but that discretion has a limit.179 A workable limit would be to imvalidate statutes that create new causes of action involving private parties and that authorize administrative determinations of these private rights outside the scope of a comprehensive regulatory scheme. If Congress has not created a comprehensive regulatory scheme, then the Court should conclude that (1) the right involved is not a public right and (2) the legal remedies are not "inadequate."

The several dimensions of the public rights concept are all consistent with the conclusion that a right is not a "public right" unless it is created as part of a comprehensive regulatory scheme. A public right may imply the vindication of a public interest. ${ }^{180}$ By creating a comprehensive regulatory scheme, Congress implies that it has found a public benefit sufficient to warrant substantial expenditures of resources, even if rights under the scheme are enforced by private individuals. Private matters may be imbued with the public interest when Congress recognizes an emergency and responds by creating a regulatory scheme. ${ }^{181}$ Furthermore, Congress's efforts to ensure uniform public compliance with its statutory goals are clearest when it enacts a broad regulatory scheme. ${ }^{182}$ Finally, using substantial governmental involvement as the defining criterion for the public rights concept is consistent with the Court's past efforts to define, or to avoid defining, the concept. ${ }^{183}$

177. Theoretically, S. 558 could also pass Schor's four-part article III test. For a discussion of the test, see supra notes 105-09 and accompanying text.

178. Northern Pipeline Constr. Co. v. Marathon Pipe Line Co., 458 U.S. 50, 80 (1982) (plurality opinion); J. Friedenthal, M. Kane \& A. Miller, Civil Procedure $\S 11.6$, at 500 (1985).

179. See, e.g., Northern Pipeline, 458 U.S. at 84; see also James, supra note 19, at 656.

180. See Luneburg \& Nordenberg, Specially Qualified Juries and Expert Nonjury Tribunals: Altermatives for Coping with the Complexities of Modern Civil Litigation, 67 VA. L. REv. 887, 966 (1981).

181. Cf. Block v. Hirsh, 256 U.S. 135, 154-55, 158 (1921) (statutory regulation of rental housing in wake of World War I).

182. See Luneburg \& Nordenberg, supra note 180, at 965 (lower court cases suggest that one of principal purposes of action based on public right is to ensure uniform compliance with statutory requirements).

183. See supra notes $68-70,94-95$ and accompanying text. The action that the Court will undertake is in inany ways analogous to "state action" analysis under the fourteenth amendinent. Many of the constraints stated in the Constitution apply only to governinents; the Court will scrutinize actions that have both governinental and private elements in an effort to find state action. Public rights analysis is not dissimilar, although a finding of a public right and a finding of state action have opposite results: the seventh amendinent right to jury trial does not apply in public rights cases, but fourteenth amendinent guarantees apply only where there is state action. The state action doctrine is, if anything, more confused than the public rights doctrine. See generally Rowe, The Emerging 
By defining a seventh amendment limit based on the finding of a comprehensive regulatory scheme, the Court can reconcile Atlas Roofing's forum-dependent doctrine with earher seventh amendment caselaw that emphasized the "inadequacy of legal remedies" as the basis for the growth of equity, a nonjury forum. ${ }^{184}$ The Atlas Roofing Court analogized Congress to the King's Chancellor, noting the power of each to create new rights and remedies and provide for their adjudication in a nonjury forum if the "remedies available in courts of law were madequate."185 The Court must, however, require that Congress demonstrate the inadequacy of the legal remedies and the necessity of adjudication in an administrative forum. Congress makes this demonstration concretely by enacting a broad regulatory scheme. If limes are to be drawn, the Court should require a strong congressional showing before causing the jury trial right to be forfeited.

A critical distinction, then, between the hypothetical taxicab statute and statutes like S. $558^{186}$ is that the taxicab statute is not part of any broad regulatory scheme. It simply imvolves congressional withdrawal of a traditional common law cause of action from federal court jurisdiction. One might argue that the seventh amendment is generally mapplicable to administrative proceedings, ${ }^{187}$ or that remedies at law are "inadequate" where Congress has enacted a comprehensive regulatory scheme because of the large number of cases involved or their technical complexity. ${ }^{188}$ But the right in the taxicab statute is clearly private. The Court could use the Tull two-step seventh amendment test to uphold the right to a jury trial. ${ }^{189}$ Under this test, the cause of action is analogous to a common law debt action, and the money damages at issue are a legal remedy. Thus, under the seventh amendment, administrative adjudication under the taxicab statute would fail.

\section{CONCLUSION}

The seventh amendment right to a jury trial is inıplicated every time Congress creates a new statutory cause of action and delegates the responsibility for adjudication under the statute to an administrative

Threshold Approach to State Action: Trying to Make Sense of Flagg Brothers, Inc. v. Brooks, 69 GEO. L.J. 745 (1981).

184. See supra notes $32-45$ and accompanying text.

185. Atlas Roofing Co. v. Occupational Safety \& Health Rev. Comm'n, 430 U.S. 442,460

(1977); see Luneburg \& Nordenberg, supra note 180, at 978.

186. See supra notes $142-44$ and accompanying text.

187. See Curtis v. Loether, 415 U.S. 189, 194 (1974).

188. J. Friedenthal, M. KANe \& A. Miller, supra note 178, § 11.6, at 500.

189. See Tull v. United States, 107 S. Ct. 1831, 1835 (1987); supra notes 31-35 and accompanying text. 
agency. The Supreme Court, while stating that the seventh amendment does not generally apply to administrative adjudications, has proceeded to establish a seventh amendment limit on Congress's autliority to delegate, based on Atlas Roofing's public rights doctrine. The public riglits doctrine has received more attention in article III cases, but even in that closely related area of constitutional law, the doctrine is not well-defined. It is thus unclear whether the Supreme Court will expand the doctrine in future seventh amendment challenges, or whether the public rights doctrine will fall into disuse. The doctrine has the potential to serve as an effective and workable limit on Congress's authority, tliough the Court has never invalidated under the seventh amendment a congressional statute that delegates adjudicatory responsibility to federal agencies. The Court should refrain from excessive deference to Congress and should protect the seventh amendment from continued erosion in our growing administrative state. Witlout clear seventh amendment guidance, Congress will continue to create administrative agencies and delegate more and more adjudicatory power to thein, slowly eroding the constitutional protections provided by the jury system.

Paul K. Sun Jr. 